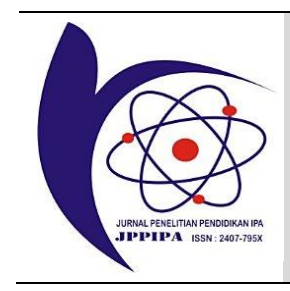

\title{
Analysis of the Impact of Coulomb Stress Changes of Tehoru Earthquake, Central Maluku Regency, Maluku Province
}

\author{
Matheus Souisa ${ }^{1234^{*}}$, Sisca Madonna Sapulete ${ }^{1234}$ \\ ${ }^{1}$ Department of Physics, Faculty of Mathematics and Natural Sciences, University of Pattimura, Ambon, Indonesia. \\ ${ }^{2}$ Landslides Laboratory, Faculty of Mathematics and Science, University of Pattimura, Ambon, Indonesia. \\ ${ }^{3}$ Disaster Mitigation Laboratory, Faculty of Mathematics and Science, University of Pattimura, Ambon, Indonesia. \\ ${ }^{4}$ Geosciences Center, Faculty of Mathematics and Science, University of Pattimura, Ambon, Indonesia.
}

DOI: $10.29303 /$ jppipa.v7i4.975

\section{Article Info}

Received: September 20th 2021

Revised: October 9'th, 2021

Accepted: October 10th, 2021

\begin{abstract}
The Tehoru earthquake occurred due to the release of stress in rocks. There is a release of energy as an earthquake as a result of the rock elasticity limit has been exceeded because the rock is no longer able to withstand the stress. One method to determine the distribution of earthquake stress is the Coulomb stress change method. The study aimed to determine the $\triangle \mathrm{CS}$ of the Tehoru earthquake, Seram Island, and the effect of the main earthquake stress release on aftershocks. The research results show that the $\Delta$ CS distribution of the Tehoru June 16, 2021 earthquake is shown with negative lobes and positive lobes. The negative lobe is found in an area that is perpendicular to the fault plane and has been identified as having experienced relaxation, so there may be still aftershocks with stress values ranging from $(0.0-0.3)$ bar. The dominant positive lobe occurs next to the southern end of the fault plane, too much located in the area of increasing Coulomb stress with values ranging from $(0.2-0.6)$ bar.
\end{abstract}

Keywords: Tehoru earthquake; fault; Coulomb stress change; aftershock.

Citation: Souisa, M., \& Sapulete, S.M (2021). Analysis of the impact of Coulomb stress changes of Tehoru earthquake, Central Maluku Regency, Maluku Province. Jurnal Penelitian Pendidikan IPA, 7(4), 593-600. doi:https://doi.org/10.29303/jppipa.v7i4.975

\section{Introduction}

The Maluku Islands are an area of eastern Indonesia that is prone to tectonic earthquakes. Maluku lies within a highly complex tectonic region resulting from the collision of the Australian and Sunda blocks and the interaction of the Pacific- Caroline and Philippine Sea plates (Souisa, 2018; Supendi et al., 2020). These three tectonic plates collide with each other, so the Maluku Islands often experience high seismic activity. The seismicity in the Banda Sea is a result of collisions between the Australian continental plate and the Banda Arc (Souisa, 2018). The collision between the plates resulted in faults that made Maluku and its surroundings tectonic earthquakes (Bock et al., 2003).
Therefore, every year seismicity is increasing in the Maluku islands.

One of the areas of the Maluku islands that are prone to earthquakes is Seram Island. There are two systems that limit Seram Island, namely the fault system in the north of Sorong and the Tarera-Aiduna fault in the south. Seram Island is formed from rising faults with sharp angles to horizontal faults, which are generally in the form of rising faults and anticline axis trending northwest-southeast (Kumparan, 2019). Evidence in the field of this horizontal fault is a change in the direction of river flow. This horizontal fault is a change in the direction of river flow controlled by a horizontal fault and an offset from the existing rock. 
BMKG noted that the Tehoru earthquake, Central Maluku Regency, occurred on June 16, 2021, at 13:43 WIB with a magnitude of $6.1 \mathrm{Mw}$. The epicenter of the earthquake was at coordinates $-3.39^{\circ} \mathrm{N}, 129.56^{\circ} \mathrm{E}$ at a depth of $14.4 \mathrm{~km}$. The impact of this earthquake on the community reached an intensity scale of IV MMI (Modified Mercalli Intensity). The impact of the Tohoku earthquake caused damage to houses, liquefaction, ground motion, and the potential for a tsunami (Figure 1). The Tehoru earthquake resulted in no casualties, and the community fled to a safe area. Recorded aftershocks, latest first (49 quakes).

The location of the epicenter is an area with active tectonics. This tectonic activity causes volcanic rocks in

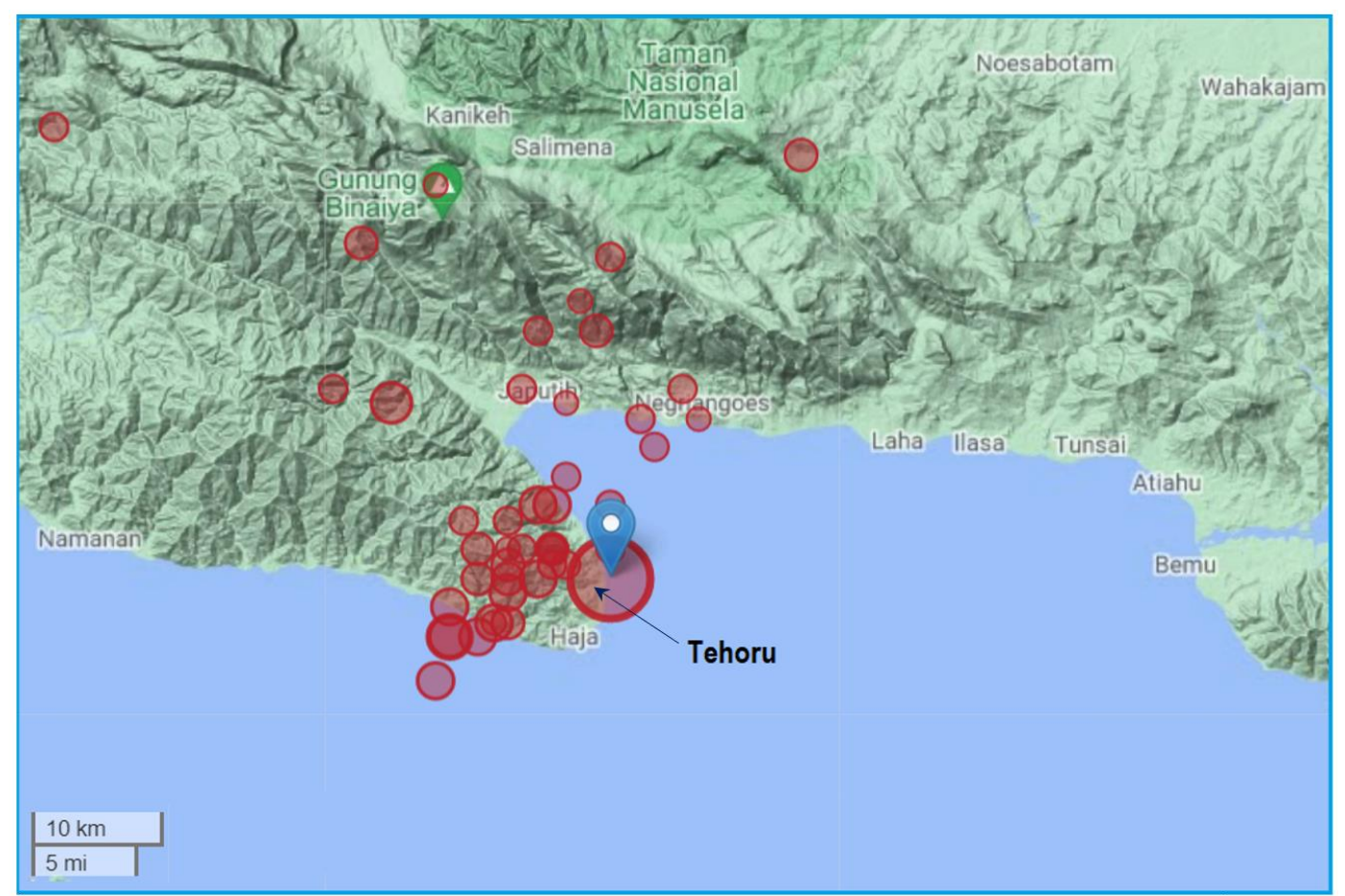

Figure 1. The updated intensity map of the Tehoru earthquake (Anonymous, 2021)

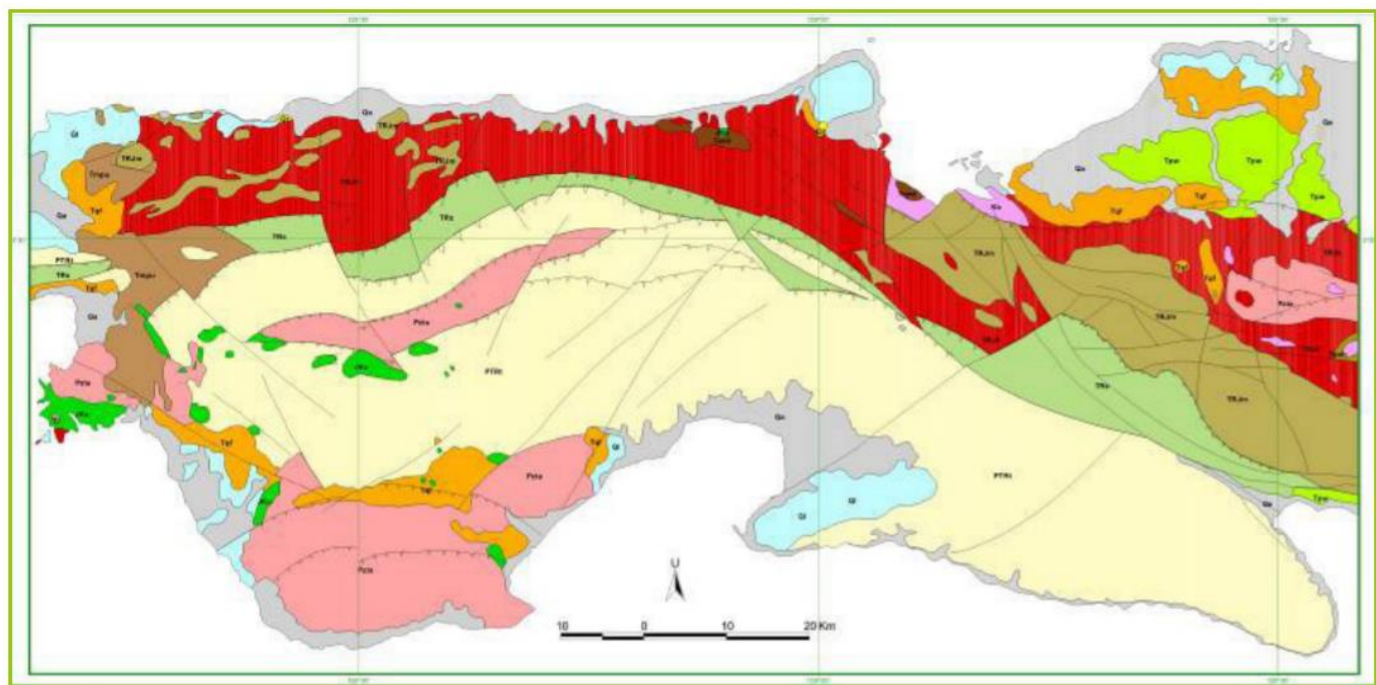

\begin{tabular}{|c|c|c|c|c|c|c|c|}
\hline \multicolumn{3}{|c|}{ Legend: } & \multirow[b]{2}{*}{ Formasi Wahai } & \multirow[b]{2}{*}{ Ks } & \multirow[b]{2}{*}{ Formasi Sawai } & \multirow[b]{2}{*}{ Tros } & \multirow[b]{2}{*}{ Formasi Saku } \\
\hline aa & Aluvial & Taw & & & & & \\
\hline a & $\begin{array}{l}\text { Batugamping } \\
\text { Koral }\end{array}$ & $\pi$ & Granit Ambon & Tmpu & $\begin{array}{l}\text { Satuan Tektonik } \\
\text { Ulii }\end{array}$ & PIRt & Komplek Tehuru \\
\hline at & Konglomerat & Tort & Formasi Lisabata & TRUm & Formasi Manusela & Pats & Komplek Taunuse \\
\hline Tat & Formasi Fufa & Tpen & Formasi Hatuolo & ina & Kompleks Kanikeh & siu & Batuan Ultramafik \\
\hline
\end{tabular}

Figure 2. Regional geological map of the study area (Sumardi et al., 2011) 
the path above the Benioff line, the emergence of ultrabasic rocks, and the formation of the Salas Complex in Sheet Masohi (Tjokrosapoetro et al., 1994). The Tehoru stratigraphy (Figure 2) covers the Tehoru Complex (PTrt) consisting of phyllite, slate, marbled limestone, and some schist; Taunusa Complex (Pzta), which consists of schist, quartzite, genes, amphibolite, marble, and phyllite; Then there is surface sedimentary rock or Alluvium (Ql). Seram Island and its surroundings are located close to the Seram Trench, so it is easy to generate large thrust earthquakes. A more detailed explanation of the source of this earthquake is not yet available. If viewed from the moment tensor of the earthquake, this earthquake could occur from a horizontal fault in the northeast-northwest direction with an almost horizontal dip with left-lateral movement. This earthquake generator could be a structure that crosses the Tehoru area from the southwest to the northeast, which generally corresponds to the normal fault lineation in the Taluti Bay section.

The occurrence of earthquakes is caused by the release of stress in the rock. There is a release of energy as an earthquake as a result of the rock elasticity limit has been exceeded because the rock is no longer able to withstand the stress. One method to determine the distribution of earthquake stress is the Coulomb stress change method( $\Delta C S$ ) (King, 2014). In addition, there is considerable evidence that the transfer of $\Delta \mathrm{CS}$ (either coseismic or postseismic) caused by major earthquakes may contribute to changes in seismicity or even trigger large earthquakes (e.g., Gomberg et al., 2021, Kilb et al., 2002, Hiwa et al., 2019). $\Delta$ CS modeling may help understand the stress distribution and explain fault interactions in Seram Island. $\triangle \mathrm{CS}$ can be used to determine the distribution of aftershocks (King, 2014). $\Delta \mathrm{CS}$ has been widely used to describe the interaction of earthquakes in their stress fields. For this reason, the research was conducted to determine the $\Delta \mathrm{CS}$ of the Tehoru earthquake, Seram Island, and the effect of the main earthquake stress release on aftershocks.

When the earthquake occurred, the community around the coast immediately evacuated independently because the Central Maluku District Government and the Regional Disaster Management Agency (BPBD) have provided socialization of earthquake and tsunami mitigation to the community before the earthquake. After the Tohoku earthquake, the local government carried out a review and assessment. The government coordinates and assists in the form of necessities for people who are temporarily displaced. The assistance provided was in the form of necessities, as well as assistance for repairing damaged houses.

\section{Methods}

\section{The seismic data}

Seismicity data taken from the Global CMT catalog combined with the USGS catalog was then confirmed with the BMKG catalog. The data entered into this catalog is from June 16, 2020, until June 16, 2021. The seismicity coordinates are $2.62^{\circ}$ South Latitude and $130.28^{\circ}$ East Longitude with a radius of $70.0 \mathrm{~km}$ around it. Then fourth aftershocks above $3.5 \mathrm{Mw}$ were recorded in the catalog. The input data for $\Delta \mathrm{CS}$ used a $6.1 \mathrm{Mw}$ earthquake on June 16, 2021, calculated on two nodal planes.

\section{The Calculation of Coulomb stress change model}

The Mohr-Coulomb failure criterion states that the shear stress $\tau$ on a fault that ruptures must surpass the critical value $\tau_{\mathrm{f}}$ (Figure 3), which is a linear function of the normal stress (Souisa, 2018; Navas-Portella et al., 2020),

$$
\tau_{f}=c+\mu^{\prime} \sigma_{n}
$$

with $c$ the cohesion and $\mu^{\prime}$ the effective fault friction coefficient (including the contribution of the pore pressure). Care must be taken with the convention of signs in the normal stress, which is not the same in geophysics than in solid mechanics (Cocco and Rice, 2002). Figure 3 shows the Mohr circle as the potential position of the crack plane, with the formula as,

$$
\begin{aligned}
& \left(\sigma-\frac{\sigma_{1}+\sigma_{3}}{2}\right)^{2}+\tau^{2}=\left(\frac{\sigma_{1}-\sigma_{3}}{2}\right)^{2} \\
& \text { or } \quad\left(\sigma-\sigma_{a v r}\right)^{2}+\tau^{2}=r^{2}
\end{aligned}
$$

Eq. (2) and (3) are Mohr's circle equations as the potential position of the crack plane (Souisa, 2018).
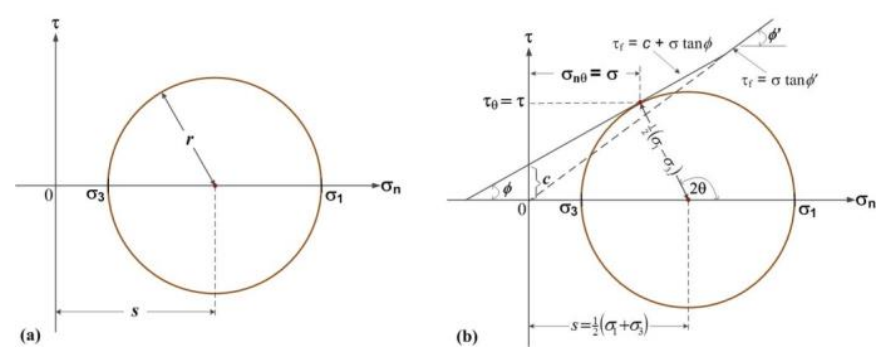

Figure 3. Mohr's stress circle. (a) Geometry and (b) stress representation (Souisa, 2018).

One of the most straightforward and powerful physics-based methods to forecast the distribution of triggered seismicity is Coulomb stress change modeling (Cocco and Rice, 2002; Toda et al., 2005). The Coulomb stress change model is commonly written as,

$$
\Delta C S=\Delta \tau+\mu\left(\Delta \sigma_{n}-\Delta P\right)
$$


where $\Delta \tau$ is the shear stress change along with slip on the fault, $\Delta \sigma_{n}$ is the normal stress change on the fault, $\Delta P$ is the pore pressure changes, and $\mu$ is the friction coefficient. The pore pressure changes $\Delta P$ is usually proportional to the volumetric stress changes under undrained conditions, as:

$$
\Delta P=-B \frac{\Delta \sigma_{k k}}{3}
$$

where $B$ is the Skempton coefficient (Cocco and Rice, 2002) with a range between 0.5 and 1 depending on the rock material, $\Delta \sigma_{k k}$ is the value of normal stress. In the isotropic case, $\Delta \sigma_{11}=\Delta \sigma_{22}=\Delta \sigma_{33}$ and $\Delta \sigma_{\mathrm{kk}} / 3=\Delta \sigma$ (average stress), thus (Lin et al., 2019):

$$
\Delta P=-B \Delta \sigma_{n}
$$

which $B$ is the Skempton coefficient that varies between 0 and 1. Substituting Eq. (6) in Eq. (4) gives the following equation:

$$
\Delta C S=\Delta \tau+\mu^{\prime} \Delta \sigma_{n}
$$

where $\Delta \sigma_{n}$ is the normal stress (positive unclamping) and $\mu^{\prime}=\mu(1-B)$ is the apparent coefficient of friction of the fault rupture plane. The values for the effective friction coefficient range from 0.0 to 0.8 . In this calculation, I take the coefficient of friction $\mu^{\prime}=0.4$ (Stein et al. 1992 in (Lin et al., 2019). The value of $\Delta \tau$ in Eq. (7) must always be positive, but the stress calculation process on a fault can be positive or negative depending on the potential slip directly to the right or the left.

The calculations of $\Delta C S$ on rock faults due to earthquakes depend on the geometry and distribution of the slip, the assumed magnitude, regional stress orientation, and the value of the assumed coefficient of friction. In some earthquakes, the $\Delta \mathrm{CS}$ uncertainty is always dominated by the slip distribution uncertainty.

In the coordinate system (Figure 4), it is shown that the failure plane is subject to the primary stress component $\left(\sigma_{\mathrm{n}}\right)$, which will produce shear stress on the failure plane. The primary stress orientation towards the angle $(\beta)$ on the failure plane will increase $\left(\sigma_{1}\right)$ and decrease $\left(\sigma_{3}\right)$ the stress on the failure plane.

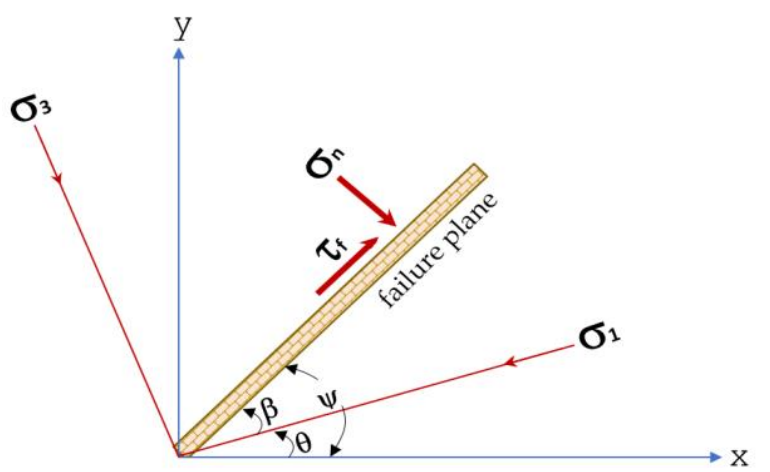

Figure 4. The coordinate system used for calculations of Coulomb stresses on optimum failure planes (King, 2014).

\section{Result and Discussion}

The Tehoru earthquake on June 16, 2021, has two types of fault parameters from Global CMT and USGS calculations and then synchronized with BMKG data (Table 1). This parameter is used to calculate $\Delta \mathrm{CS}$ and display the $\Delta C S$ cross-section caused by an earthquake or display the $\Delta \mathrm{CS}$ dispersion pattern of rocks vertically based on depth. The earthquake source mechanism issued by the three institutions shows compatibility with one another, namely, the earthquake is caused by active fault activity in the form of a normal fault trending northeast-southwest with shallow depth in the crustal

\begin{tabular}{|c|c|c|c|c|c|c|}
\hline Time & $\begin{array}{l}\text { Episenter } \\
(0)\end{array}$ & $\begin{array}{l}\text { Depth } \\
(\mathrm{km})\end{array}$ & $\begin{array}{l}\text { Mag } \\
(\mathrm{Mw})\end{array}$ & $\begin{array}{l}\text { Strike } \\
(0)\end{array}$ & $\begin{array}{l}\text { Dip } \\
\left(^{0}\right)\end{array}$ & $\begin{array}{l}\text { Rake } \\
\left({ }^{0}\right)\end{array}$ \\
\hline June & 129.56 & & & 246 & 45 & -48 \\
\hline 2021 & -3.39 & 14,4 & 6,1 & 14 & 58 & -124 \\
\hline
\end{tabular}
earthquake.

Table 1. Parameters of the Tehoru earthquake

Calculation of $\Delta \mathrm{CS}$ and the effect of stress release of the Tehoru earthquake, two different types of fault parameters are used, namely strike angle, dip, and rake. The modeling uses two different nodes with a depth of $14.4 \mathrm{~km}$. The first nodal plane is a horizontal fault in a northeast-southwest direction with a nearly horizontal dip with a left lateral movement, and the second nodal plane is the result of a right-lateral movement in a northsouth direction. This calculation uses a friction coefficient value of 0.4 .

After processing, the $\Delta \mathrm{CS}$ distribution of the primary earthquake varies spatially. In Figure 5, a negative $\Delta$ CS value or there is a decrease in rock stress at the fault plane location. Rock stress in the fault plane area decreases because it has been released in the form of earthquakes. Horizontally, the $\Delta \mathrm{CS}$ distribution appears to have three dominant positive lobes occurring at the side end of the fault plane or in the direction of the fault plane and spreading in the northeast-southwest direction with stress values ranging from (0.1 to 1.0) bar. While the two dominant-negative lobes occur in the area perpendicular to the fault plane and spread in the northwest-southeast direction with stress values ranging from -0.1 bar to -1.0 bar. The negative lobe appears dominant and spreads around the fault plane for approximately $67.5 \mathrm{~km}$ to reach the eastern part of Masohi City. Meanwhile, the positive lobe spread to Negeri Saunulu, Negeri Yaputi, and Negeri Haya.

If the $\Delta \mathrm{CS}$ distribution of rock is modeled vertically concerning depth, then it is carried out by cross-section at a depth of $50.0 \mathrm{~km}$ and a length of 100.0 $\mathrm{km}$ (Figures 6(b) and 7(b)). When viewed from the crosssection, aftershocks occurred at a distance of $<60.0 \mathrm{~km}$ with a depth of $\leq 40.0 \mathrm{~km}$ below the earth's surface. The 
cross-section shows that this earthquake is in a relaxation area with the potential for failure so that the number of earthquakes that may occur in the relaxation area tends to increase. According to the cross-section, this earthquake is located in an area of increased Coulomb stress (positive lobe) which is possible that the earthquake was triggered by the main earthquake, which caused aftershocks (faults), and another aftershock can occur again in the future in the area. with positive stress with depth $\leq 40.0 \mathrm{~km}$ and DCS distribution ranging from $(0.1-1.0)$ bar or $(0.01-0.1)$ $\mathrm{MPa}$. Aftershock activities may be promoted or triggered when the Coulomb stress on the fault plane is (negative lobe) tend to provide balance in areas of increased stress (positive lobe).

The Tehoru earthquake had a significant impact on the surrounding area (Toda et al., 2005; Parsons et al., 2006; Parsons et al., 2008). The increasing Coulomb stress changes will promote the occurrence of shallow focus aftershocks outside of the Taluti bay. Since shallow aftershocks are expected to have a higher damage potential, this is a valuable constraint for postmainshock mitigation efforts (Madlazim, 2015). In addition, $\Delta$ CS calculations show that the Tehoru earthquake only occurs in areas of positive stress change from the primary earthquake. Of course, it is $\Delta \mathrm{CS}$

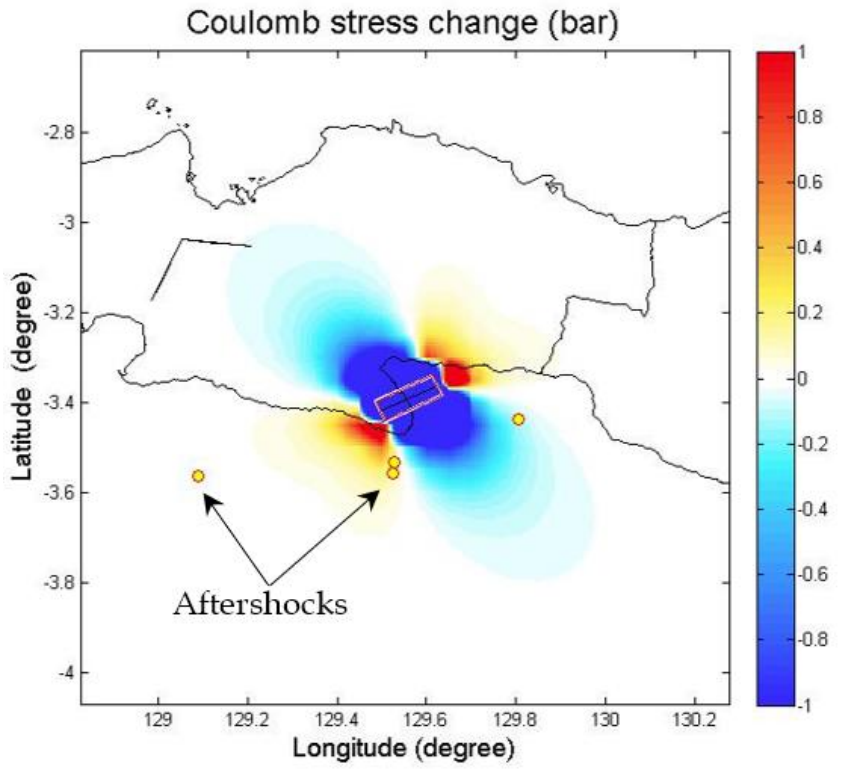

(a)

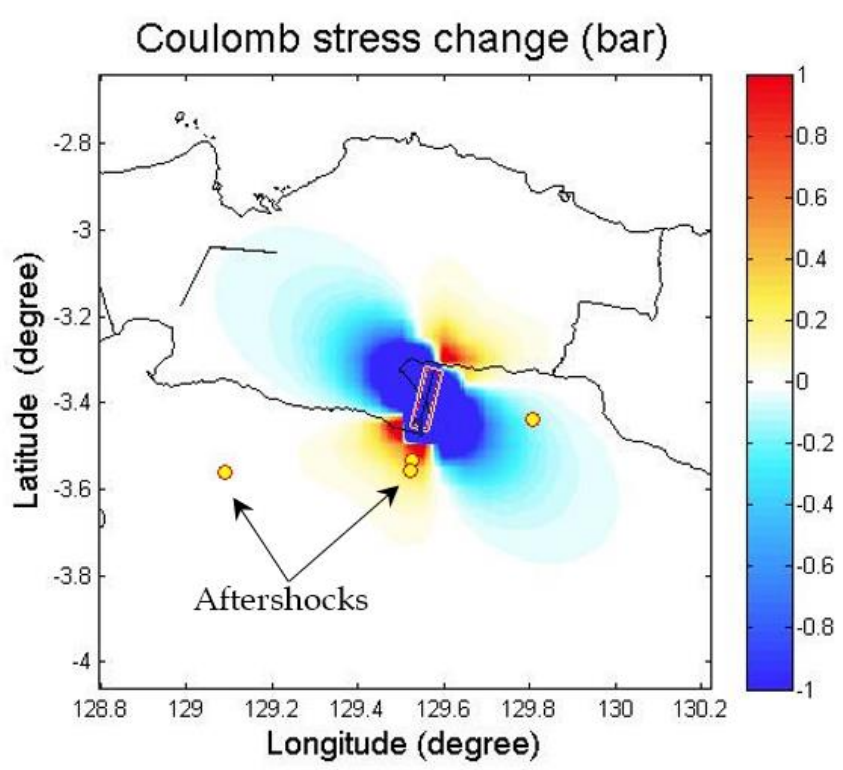

(b)

Figure 5. The Coulomb distribution of the primary earthquake stress overlaid with the distribution of the epicenter of the aftershocks (red circle). (a) The Coulomb stress distribution uses the first nodal plane, and (b) the $\Delta$ CS distribution uses the second nodal plane.

increased by as little as 0.1 bar (Toda et al., 2005; Wu et al., 2015). The $\mathrm{Mw}>3,5$ aftershocks distribution are well explained by the seismic coulomb stress changes caused by the Tehoru Mw 6.1 primary shock. Three in four $M>$ 3.5 aftershocks occurred in the positive coulomb stress area with stress values ranging from $(0.2-06)$ bar.

Figures 6 and 7 show that the vertical coulomb stress distribution pattern showing the hypocenter of an earthquake with a depth of $14.4 \mathrm{~km}$ has a large enough increase in coulomb stress of about 1 bar $(0.1 \mathrm{MPa})$. This means that aftershocks are likely to occur with a fairly high frequency and large magnitude. This is indicated by the positive lobe, which is an area that still has high stress and tends to generate aftershocks. While in the negative lobe, identified stress has been released and experienced relaxation, and the possibility of aftershocks is very small. For fault, areas with decreased stress calculation on the slip model, receiver error, and other parameters, such as depth and effective friction coefficient, which causes some discrepancies in displaying results (Wan et al., 2000; Miao and Zhu, 2012).

These aftershocks took place continuously for approximately two months, from June 16, 2021, to September 9, 2021. This indicates that the main earthquake, which has a low-stress drop value ( $\leq 1.0$ bar) as shown in Figure 5, tends to produce more aftershocks because the energy released is large enough $(0.1 \mathrm{MPa})$ to cause a widespread increase in stress on the rock. This illustrates that the closest location to the epicenter of the earthquake is Tehoru, located in Taluti Bay. The location is predominantly composed of coastal and river alluvial deposits. Most of the hills are composed of the Tehoru Complex Formation in the form of metamorphic rocks of 
Pre-tertiary age and the $\mathrm{OH}$ Formation of Neval and Naval Tufan of Tertiary ages (ESDM, 2021). Some PreTertiary and Tertiary rocks have undergone weathering and are decomposed, soft, loose, unconsolidated so that they are easy to shift when stress is distributed. Weathered rock will generally amplify the effects of earthquake shocks so that earthquake shocks will be more pronounced when exposed to large amounts of energy through the distribution of stress on the rock. structural mitigation such as planting mangrove trees, constructing breakwater buildings along the coast, constructing houses that can absorb earthquakes, and improving evacuation route signs and assembly points. In addition to structural mitigation, the public also needs to be given education about non-structural mitigation such as periodic earthquake mitigation socialization, making earthquake and tsunami hazard maps and getting earthquake information through social media.

The 2021 Tehoru (Seram Island) earthquake when

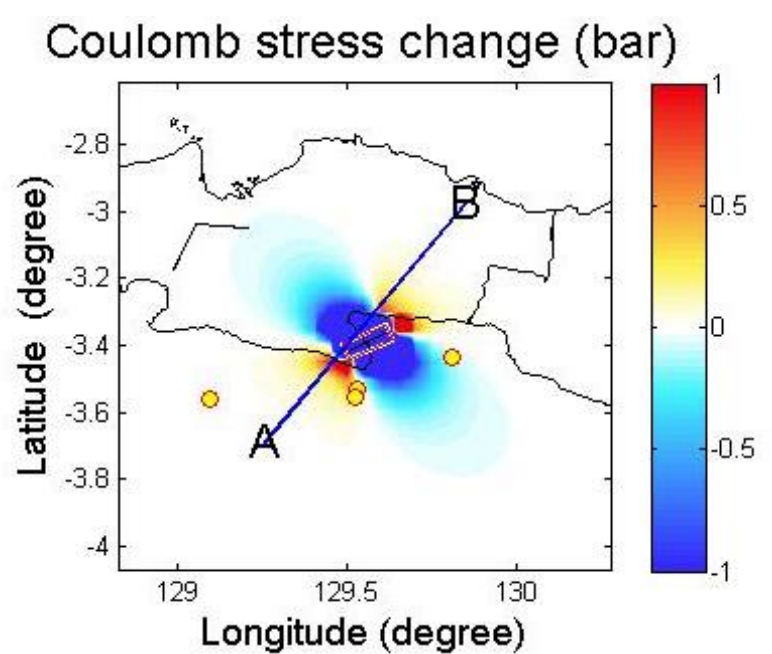

(a)

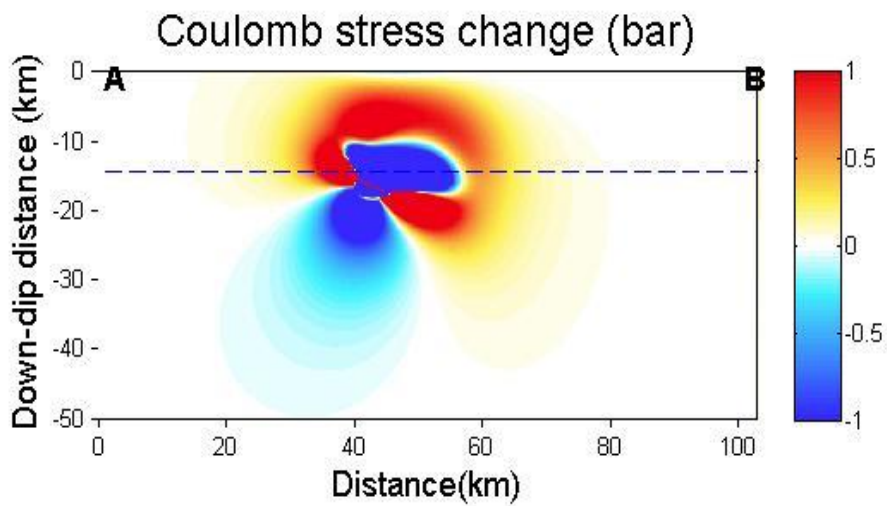

(b)

Figure 6. (a). Coulomb stress with fault parameter in the first nodal plane, (b). Cross-section with fault parameters in the first nodal plane.

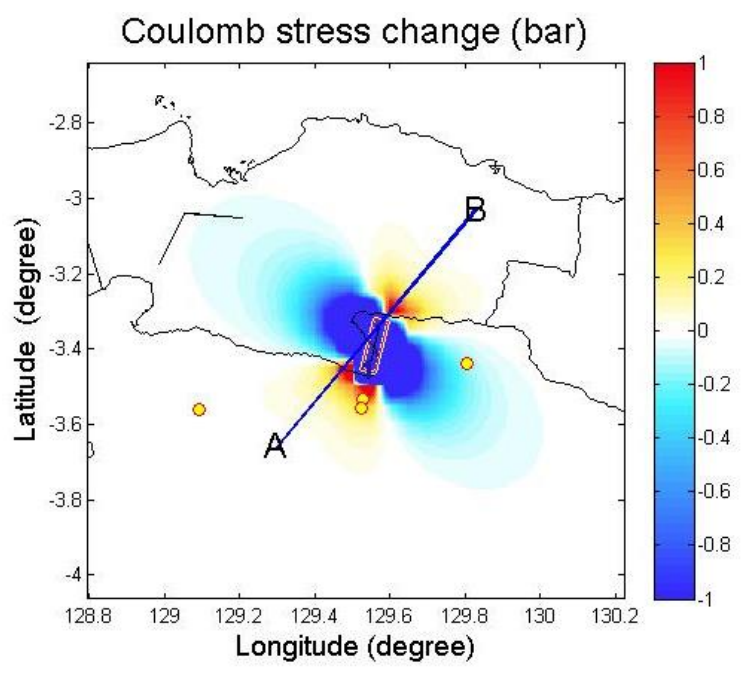

(a)

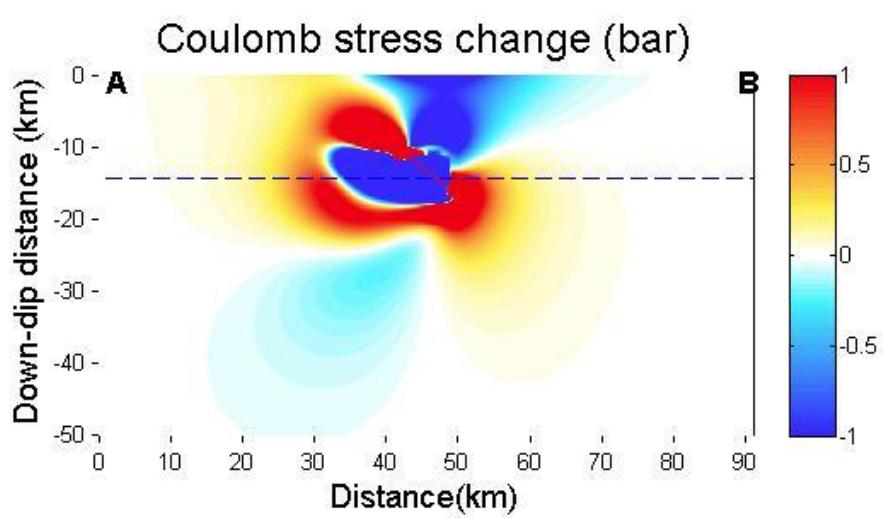

(b)

Figure 7. (a). Coulomb stress with fault parameter in the second nodal plane, (b). Cross-section with fault parameters in the second nodal plane.

In the study area, the potential for earthquakes can occur at any time, and based on the DCSC analysis, this area is prone to faults and can cause underwater landslides. Therefore, the community needs to obtain compared with data on the Kairatur (Seram-Ambon) earthquake on September 26, 2019. The Kairatu earthquake originated from a dextral and bilateral horizontal fault with a south-north orientation. The total 
seismic moment of this earthquake is equivalent to a moment magnitude of 6.5. The Kairatu earthquake had a relatively low-stress drop (Sianipar et al., 2019). Aftershocks have a slow decay rate. The $\Delta \mathrm{CS}$ of the rock caused a large number of Kairatu aftershocks in the area surrounding the main earthquake, similar to the Tohoku earthquake. This identifies that the energy released is large enough to be able to generate the aftershocks of the Tehoru and the aftershocks of Kairatu.

\section{Conclusion}

Based on the discussion that has been stated previously, it can be concluded that: the distribution of the Coulomb stress change $(\Delta \mathrm{CS})$ of the Tehoru June 16, 2021, earthquake is described by the dominant-negative lobe occurring in an area perpendicular to the fault plane which has been identified to have relaxed, but there may be still aftershocks with stress values ranging from $(0.0$ 0.3 ) bar. Furthermore, the dominant positive lobe occurs at the side end of the fault plane due to the influence of the dominant earthquake source mechanism in the form of normal faults. The location of the epicenter distribution of the aftershocks concentrated in the south of the fault plane is mostly located in the area of increasing Coulomb stress with values ranging from (0.2 - 0.6) bar.

\section{Acknowledgements}

Thank you to the Geoscience Center, Faculty of Mathematics and Natural Sciences, Pattimura University, which has prepared facilities for data analysis, and all parties who have supported the completion of this research.

\section{References}

Anonymous. (2021). Very strong mag. 6.0 earthquake Seram, Indonesia, on Wednesday, June 162021 at 04:43 (GMT) - information, Volcano Discovery. Retrieved from: https://www.volcanodiscovery.com/...magnitu de6-Indonesia.html

Bock. Y., Prawirodirdjo. L., Genrich, J. F., Stevens, C.W., McCaffrey, R., Subarya., Puntodewo. S.S.O., \& Calais, E. (2003). Crustal Motion in Indonesia from Global Positioning System Measurements. Journal of Geophysical Research: Solid Earth. 108(B8), 2367, ETG 3-1-ETG3-21. doi: https://doi.org/10.1029/2001JB000324

Cocco, M., \& Rice, J. R. (2002). Pore pressure and poroelasticity effects in Coulomb stress analysis of earthquake interactions. Journal of Geophysical
Research: Solid Earth, 107(B2), ESE 2-1-ESE 2-17. https://doi.org/https://doi.org/10.1029/2000JB 000138.

ESDM. 2021. Laporan Singkat Dan Rekomendasi Teknis Gempa Bumi Tanggal 16 Juni 2021 Di Kabupaten Maluku Tengah, Provinsi Maluku. Diakses dari: https://vsi.esdm.go.id/index.php/...-provinsimaluku [Indonesian]

Gomberg, J., Reasenberg, P. A., Bodin, P., \& Harris, R. A. (2001). Earthquake triggering by seismic waves following the Landers and Hector Mine earthquakes. Nature, 411(6836), 462-466. https://doi.org/10.1038/35078053

Hiwa, M., Quigley, M., Steacy, S., \& Brendan, D. (2019). Effects of source model variations on Coulomb stress analyses of a multi-fault Intraplate earthquake sequence. Tectonophysics, 766, 151-166. doi: https://doi.org/10.1016/j.tecto.2019.06.007

Kilb, D., Gomberg, J., \& Bodin, P. (2002). Aftershock triggering by complete Coulomb stress changes. Journal of Geophysical Research, 107(B4), ESE-2. https://doi.org/10.1029/2001JB000202

King, G.C.P. (2014). Static Stress Changes and the Triggering of Earthquakes by King, G.C.P., Stein, R.S. \& Lin, J. (1994). Bulletin of the Seismological Society of America, 84(3), 935-953. Retrieved from https://www.researchgate.net/publication/237 $\underline{500715}$

Kumparan. (2019). Mengenal Kondisi Geologi Pulau Seram: Ambon, Maluku, diakses pada tanggal 5 September 2021. Retrieved from: https://kumparan.com/... 1rwktbBY8R0/full. [Indonesian]

Lin, X., Chu, R., \& Zeng, X. (2019). Rupture processes and Coulomb stress changes of the $2017 \mathrm{Mw} 6.5$ Jiuzhaigou and $2013 \mathrm{Mw} 6.6$ Lushan earthquakes. Earth, Planets and Space, 71(1), 81. https://doi.org/10.1186/s40623-019-1061-3.

Madlazim. (2015). Coulomb Stress Changes Due To Recent Aceh Earthquakes. Jurnal Penelitian Fisika Dan Aplikasinya (JPFA), 5(1), 9-14. https://doi.org/10.26740/ipfa.v5n1.p9-14

Miao, M., \& Zhu, S. (2012). A study of the Impact of Static Coulomb Stress Change of Megathrust Earthquakes Along Subduction Zona on the Following Aftershocks, Chinese Journal of Geophysics, 55(5), 539-551. https://doi.org/https://doi.org/10.1002/cjg2.17 $\underline{48}$.

Navas-Portella, V., Jiménez, A., \& Corral, Á. (2020). No Significant Effect of Coulomb Stress on the Gutenberg-Richter Law after the Landers Earthquake. Scientific Reports, 10(1), 2901. https://doi.org/10.1038/s41598-020-59416-2.

Parsons, T., Yeats, R. S., Yagi, Y., \& Hussain, A. (2006). Static stress change from the 8 October, $2005 \mathrm{M}=$ 
7.6 Kashmir earthquake. Geophysical Research

Letters, 33(6).

https://doi.org/https://doi.org/10.1029/2005G L025429

Parsons, T., Yeats, R. S., Yagi, Y., \& Hussain, A. (2006). Static stress change from the 8 October, $2005 \mathrm{M}=$ 7.6 Kashmir earthquake. Geophysical Research Letters, 33(6). https://doi.org/https://doi.org/10.1029/2005G $\underline{\mathrm{L} 025429}$.

Sianipar, D., Halauwet, Y., Daryono., \& Karnawati, D. (2019). Studi Sumber Gempa Ambon 26 September $2019 \mathrm{Mw}$ 6,5. Preprint, 1-20. doi: https://doi.org/10.31227/osf.io/6e9nm [Indonesian]

Souisa, M. (2018). Physics model movement of cover steep slopes in Ambon Island Moluccas. Doctoral Dissertation (pp.44,113), Institut Teknologi Bandung. Retrieved from https://digilib.itb.ac.id/index.php/gdl/view/2 $\underline{8794}$.

Supendi, P., Nugraha, A. D., Widiyantoro, S., Pesicek, J. D., Thurber, C. H., Abdullah, C. I., Daryono, D., Wiyono, S. H., Shiddiqi, H. A., \& Rosalia, S. (2020). Relocated aftershocks and background seismicity in eastern Indonesia shed light on the 2018 Lombok and Palu earthquake sequences. Geophysical Journal International, 221(3), 1845-1855. https://doi.org/10.1093/gji/ggaa118

Sumardi, E., Bakrun, Syuhada., \& Rihardiana, L. (2011). Survei Geofisika Terpadu Banda Baru, Maluku Tengah, Provinsi Maluku. Pusat Sumber Daya Geologi, Badan Geologi Bandung, 1-18. Retrieved from: $\quad$ http://psdg.bgl.esdm.go.id/....pdf [Indonesian]

Tjokrosapoetro, E., Rusmana, E., \& Achdan, A. (1994). Geological Map of the Ambon Sheet Maluku, Direktorat Jenderal Geologi dan Sumberdaya Mineral, Pusat Penelitian dan Pengembangan Geologi (Bandung), 3-11.

Toda, S., Stein, R., Richards-Dinger, K., \& Bozkurt, S. (2005). Forecasting the evolution of seismicity in Southern California: Animations built on earthquake stress transfer. Journal of Geophysical Research B: Solid Earth, 110(5), 1-17. doi: https:// doi.org/10.1029/2004JB003415

Wan, Y. G., Wu, Z. L., \& Zhou, G.W. (2000). Stress triggering" between different rupture events in several earthquakes. Acta Seismologica Sinica (in Chinese), 22(6), 568-576. doi: https://doi.org/10.1007/s11589-000-0062-3

Wu, J., Hu, Q., Li, W., \& Lei, D. (2016). Study on Coulomb Stress Triggering of the April 2015 M7.8 Nepal Earthquake Sequence, 1-10. Doi: http://dx.doi.org/10.1155/2016/7378920 